\title{
Belowground carbon pools and dynamics in China's warm temperate and sub-tropical deciduous forests
}

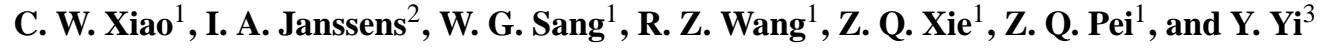 \\ ${ }^{1}$ State Key Laboratory of Vegetation and Environmental Change, Institute of Botany, the Chinese Academy of Sciences, \\ Beijing 100093, China \\ ${ }^{2}$ Department of Biology, Research Group of Plant and Vegetation Ecology, University of Antwerp, Universiteitsplein 1, \\ 2610 Wilrijk, Belgium \\ ${ }^{3}$ School of Life Sciences, Guizhou Normal University, Guiyang 550001, China
}

Received: 22 May 2009 - Published in Biogeosciences Discuss.: 1 July 2009

Revised: 25 December 2009 - Accepted: 7 January 2010 - Published: 20 January 2010

\begin{abstract}
We report the first estimates of pools and dynamics of microbes, roots, plant litter and soil organic carbon (SOC) in three dominant types of China's vast deciduous forest area: Betula platyphylla, Quercus liaotungensis, and Quercus aliena var. acuteserrata. Organic matter degradation rates overshadowed litter inputs as the main determinant of the soil carbon stocks. Across the three forests, rates of litter decomposition were also indicative for turnover rates of SOC. Litter and SOC decay was faster in the subtropical than in the warm-temperate forests. Among the latter, SOC turnover was highest in the forest producing the higher-quality litter. Microbial biomass was, as expected, correlated with SOC content. Microbial activity, in contrast, was highest at the sub-tropical forest, despite the lower SOC availability, lower fraction of labile SOC, and lower soil microbial biomass. These results may contribute to increased understanding of controls over belowground carbon cycling in deciduous forests.
\end{abstract}

\section{Introduction}

With the significant increase in atmospheric greenhouse gas concentrations and the potential for global climate change, studies of the terrestrial carbon cycle have gained attention over the last 20 years (Houghton et al., 2001; Callesen et al., 2003). Soil carbon is an important terrestrial carbon reservoir and plays a key, yet poorly understood role in the global carbon cycle and its feedback to climate change (Post et al.,

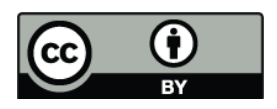

Correspondence to: C. W. Xiao

(cwxiao@ibcas.ac.cn)
1982; Davidson and Janssens, 2006). Therefore, the study of soil organic carbon (SOC) dynamics is critically important to our ability to understand the global carbon cycle and its response to future global change (Davidson et al., 2000).

Deciduous broad-leaved forests are an important forest type and the status of these forests as carbon sources or sinks has previously been assessed (Curtis et al., 2002; Stephenson and van Mantgem, 2005). Asia white birch (Betula platyphylla; about $22^{\circ}-53^{\circ} \mathrm{N}, 90^{\circ}-135^{\circ} \mathrm{E}$ ), EastLiaoning oak (Quercus liaotungensis; about $26^{\circ}-53^{\circ} \mathrm{N}, 90^{\circ}-$ $135^{\circ} \mathrm{E}$ ) and Sharptooth oak (Quercus aliena var. acuteserrata; about $22^{\circ}-39^{\circ} \mathrm{N}, 92^{\circ}-125^{\circ} \mathrm{E}$ ) are widely distributed in mountainous areas in the temperate and sub-tropical zone of China (Delectis Flora Reipublicae Popularis Sinicae Agendae Academiae Sinicae Edita, 1979, 1998) and dominate important forest types in China (Chen, 1997). However, despite their high importance for the carbon budget of east Asia (Fang et al., 2007; Feng et al., 1999), soil carbon dynamics, including soil carbon pool sizes and turnover rates, have so far not been reported for these kinds of forests.

In this study, we compared pools and dynamics of fine roots, soil carbon pools, and soil microbes among Asia white birch, East-Liaoning oak, and Sharptooth oak forests. We applied density fractionation (e.g. Elliott and Paustian, 1996; Zimmermann et al., 2007) to soil samples of the different forests to address the pool sizes and kinetics of fast- and slow cycling organic matter pools. The overall objective of this study was to examine soil carbon quantity and quality in these important forest types. The specific objectives of this study were: (1) to determine the total SOC pool and its components in the three forest types, and (2) to determine the rates of carbon cycling through the litter and SOC pools. 


\section{Materials and methods}

\subsection{Site description}

Three deciduous broad-leaved forest types were assessed in this study: (1) Asia white birch forest; (2) East-Liaoning oak forest; and (3) Sharptooth oak forest. All three forests were growing on clay-poor soils (less than $5 \%$ ), with $\mathrm{pH}$ values varying between 6.5 (Sharptooth oak) and 6.9 (Asia white birch and East-Liaoning oak). Similar clay contents and $\mathrm{pH}$ values across the three sites are favourable for comparisons of SOC pools, although we acknowledge that different clay mineralogies may exhibit different SOC stabilization potentials (Six et al., 2000). The study sites of Asia white birch and East-Liaoning oak were located in the Donglingshan Mountains, Beijing $\left(39^{\circ} 48^{\prime}-40^{\circ} 00^{\prime} \mathrm{N}, 115^{\circ} 24^{\prime}-115^{\circ} 36^{\prime} \mathrm{E}\right)$. These two sites were situated in the warm temperate climate zone, and the two sites were characterized by a warm temperate, semi-wet monsoon climate. Long-term mean annual precipitation in this area was $612 \mathrm{~mm}$ and mean annual air temperature was $4.8^{\circ} \mathrm{C}$. The soil in both stands was classified as a Eutric cambisol (FAO-WRB, 1998), with a depth of about $60 \mathrm{~cm}$. The Sharptooth oak forest was located in the Shennongjia Mountains, Hubei Province $\left(31^{\circ} 15^{\prime}-31^{\circ} 57^{\prime} \mathrm{N}\right.$, $109^{\circ}-110^{\circ} 58^{\prime} \mathrm{E}$ ). This forest was located in the sub-tropical zone, and was characterized by a sub-tropical monsoon climate, with mean annual precipitation of $1514 \mathrm{~mm}$ and mean annual air temperature of $10.6^{\circ} \mathrm{C}$. The sandy-loam soil in this forest is classified as a Haplic cambisol (FAO-WRB, 1998) with a depth of some $100 \mathrm{~cm}$.

A 0.25 ha plot of 60-year-old Asia white birch forest $\left(39^{\circ} 57^{\prime} 01^{\prime \prime} \mathrm{N}, 115^{\circ} 25^{\prime} 07^{\prime \prime} \mathrm{E}\right.$, elevation $1380 \mathrm{~m}$ a.s.l.) was selected for this study. The inclination of the site was $32^{\circ}$. The Asia white birch forest was dominated by Asia white birch, admixed with associated species (Betula utilis and Populus alba), and an abundance of shrubs including Sorbus pohuashanensis, Lonicera japonica, Prunus armeniaca, Corylus mandshurica, Acer mono, Abelia biflora, Leptodermis oblonga, Spiraea sargentiana, Macrocarpium officinalis. Tree density at the plot was 1234 trees ha $^{-1}$, with a mean diameter at breast height (DBH) of $13.2 \mathrm{~cm}$ and a mean tree height of $8.5 \mathrm{~m}$.

We also selected a 0.25 ha plot of 60 -year-old EastLiaoning oak forest $\left(39^{\circ} 57^{\prime} 04^{\prime \prime} \mathrm{N}, 115^{\circ} 25^{\prime} 04^{\prime \prime} \mathrm{E}\right.$, elevation $1200 \mathrm{~m}$ a.s.1.), with an inclination of $28^{\circ}$. This EastLiaoning oak forest was dominated by East-Liaoning oak, and admixed with $B$. utilis as associated tree species and some shrubs (S. sargentiana, A. mono, Lespedeza bicolor, L. japonica, C. mandshurica, and Deutzia scabra). Tree density was 1262 stems ha $^{-1}$, with a mean DBH of $12.2 \mathrm{~cm}$ and a mean tree height of $6.8 \mathrm{~m}$.

Last, a 0.25 ha plot of 55 -year-old Sharptooth oak forest $\left(31^{\circ} 30^{\prime} 09^{\prime \prime} \mathrm{N}, 110^{\circ} 30^{\prime} 29^{\prime \prime} \mathrm{E}\right.$, elevation $1994 \mathrm{~m}$ a.s.l.) was selected for the study. The inclination of the site was $30^{\circ}$. The Sharptooth oak forest was dominated by Sharptooth oak, ad- mixed with associated tree species such as: Cornus japonica var. Chinensis, Platyearya strobilacea, Carpinus lurczaninowii, and Viburnum betulifolium, and shrubs including: Indocalamus lessellalus, Viburnum SP., Lilsea SP., Rhus Chinensis, Abelia SP., Lespedeza SP., and Coriaria sinica. Tree density was 1296 trees ha $^{-1}$, with a mean DBH of $12.4 \mathrm{~cm}$ and a mean tree height of $7.5 \mathrm{~m}$.

Primary forests of Asia white birch and East-Liaoning oak have been intensely disturbed by human activities and disappeared completely. The contemporary Asia white birch and East-Liaoning oak forests are secondary and are currently protected and naturally regenerating (Chen, 1997). Sharptooth oak forests were much less disturbed by human activities, and although our study site was not a primary forest, it has been less intensively managed/disturbed than the other two study sites. For all three species, leaves tend to appear by the end of April, and most of the litterfall occurs between early September and end of October.

\subsection{Soil analyses}

For the determination of bulk density, five soil cores were taken at different depths $(0-5,5-15,15-30,30-45,45-$ $55 \mathrm{~cm}$ ) in all plots in May 2006. A special coring device for the determination of bulk density (volume $=100.0 \mathrm{ml}$ ) was applied. In July 2006, surface organic horizon mass was quantified with a metal cylinder inserted down to the mineral soil $(n=5)$. Five soil columns were collected in each plot for the determination of light fraction organic carbon (LF-OC), heavy fraction organic carbon (HF-OC) and total SOC. These samples were randomly taken by coring with a sharp-edged metal cylinder with an inner diameter of $3 \mathrm{~cm}$ and a length of $10 \mathrm{~cm}$. Samples were separated according to depth $(0-5$, $5-15,15-30,30-45,45-55 \mathrm{~cm})$ and the fresh samples were passed through a 2-mm sieve and manually cleaned of any visible plant tissues. Density fractionation of SOC physically separates soil into low- and high-density fractions, referred to as LF-OC and HF-OC. LF-OC is commonly referred to as a plant-derived and less stable fraction with high $\mathrm{C}$ concentration (Golchin et al., 1994). HF-OC is assumed to be a more stable and high-density organo-mineral fraction, having lower C concentrations (Golchin et al., 1995). The LFOC was determined using the density fractionation method (Sollins et al., 1984). Air-dried soils were passed through a $2 \mathrm{~mm}$ mesh sieve and $5.0 \mathrm{~g}$ (dry weight equivalent) of airdried soils was transferred to a tube and dispersed in $20 \mathrm{~mL}$ of NaI solution adjusted to a density of $1.7 \mathrm{gmL}^{-1}$. The suspension in the tube was shaken thoroughly for $15 \mathrm{~min}$, and after standing overnight, separated light and heavy fractions. The light fractions at the surface of the density liquid were aspirated, and trapped onto a membrane filter pa-

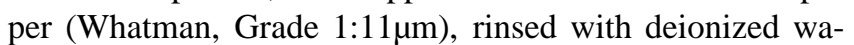
ter, and then oven-dried at $50^{\circ} \mathrm{C}$ and weighed. Total SOC and LF-OC were determined with the dichromate oxidation method (Lovell et al., 1995). Briefly, 0.2 g of ground soil 
was digested with $5 \mathrm{ml}$ of $2 \mathrm{M} \mathrm{K}_{2} \mathrm{Cr}_{2} \mathrm{O}_{7}$ and $5 \mathrm{ml}$ of concentrated $\mathrm{H}_{2} \mathrm{SO}_{4}$ at $170^{\circ} \mathrm{C}$ for $10 \mathrm{~min}$, followed by titration of the digests with $2 \mathrm{M}$ standardized $\mathrm{FeSO}_{4}$. The HF-OC was determined by subtracting LF-OC from the total SOC.

\subsection{Soil microbial biomass carbon and activity}

Five soil core samples per plot were randomly collected for determination of soil microbial biomass carbon (SMB-C) and soil microbial activity (SMA) in May, July and September 2006. Samples were taken from the $0-15 \mathrm{~cm}$ mineral soil layer using a sharp-edged metal cylinder with an inner diameter of $10 \mathrm{~cm}$ and a length of $15 \mathrm{~cm}$. Each sample was labeled, and then stored at $2{ }^{\circ} \mathrm{C}$ in a cooler for transport to the laboratory. In the laboratory, the fresh samples were passed through a $2-\mathrm{mm}$ sieve and manually cleaned of any visible plant tissues.

Soil microbial biomass carbon (SMB-C) was measured using the chloroform fumigation-extraction method (Vance et al., 1987). Twenty grams (dry weight equivalent) of fumigated and non-fumigated soil samples were extracted with $0.5 \mathrm{M} \mathrm{K} 2 \mathrm{SO} 4$. Extracts were filtered through $0.45-\mu \mathrm{m}$ filters and frozen at $-20^{\circ} \mathrm{C}$ before analysis of extractable carbon by dichromate digestion as described by Lovell et al. (1995). SMB-C was calculated as the difference in extractable carbon of fumigated and non-fumigated soil samples. To correct for incomplete extractability, a conversion factor $(\mathrm{Kec})$ of 0.38 was used to obtain SMB-C (Vance et al., 1987).

Soil microbial activity (SMA), i.e. soil microbial respiration, was estimated by determining $\mathrm{CO}_{2}$ evolution over a 2week incubation period. First, $20.0 \mathrm{~g}$ (dry weight equivalent) of soil was brought to $60 \%$ of the water holding capacity and incubated at $25^{\circ} \mathrm{C}$ for 2 weeks. Respired $\mathrm{CO}_{2}$ was captured in $5.0 \mathrm{ml}$ of $0.5 \mathrm{M} \mathrm{NaOH}$ suspended inside a Mason jar, and the $\mathrm{NaOH}$ solution was subsequently titrated to determine the amount of $\mathrm{CO}_{2}$ evolved (Hu and van Bruggen, 1997).

\subsection{Forest floor mass and litterfall}

The three forests exhibited a moder type of litter layer (Müller, 1889). Forest floor mass was measured on five randomly located, $0.5 \mathrm{~m} \times 0.5 \mathrm{~m}$ subplots from each plot in May, June, July, August, September, and October 2006 and in April 2007. Forest floor mass was sorted into coarse woody debris and surface organic matter. Litterfall was trapped and collected in May, June, July, August, September, and October 2006 and in April 2007 using five randomly located $0.45 \mathrm{~m} \times 0.35 \mathrm{~m}$ rectangular baskets, and sorted into woodyand non-woody fractions. Dry litter mass was determined after oven-drying at $75^{\circ} \mathrm{C}$ for $2-3$ days.

\subsection{Fine root biomass, production and turnover rate}

Fine root $(<2 \mathrm{~mm})$ biomass was determined in each plot by core sampling (Roberts, 1976) to a depth of $55 \mathrm{~cm}$ in May, July and September 2006. At each sampling date, 10 sample columns were randomly excavated using a sharp-edged metal cylinder with an inner diameter of $10 \mathrm{~cm}$ and a length of $20 \mathrm{~cm}$. Samples from different depths $(0-5,5-15,15-30$, $30-45,45-55 \mathrm{~cm})$ were separated and labeled. Fine roots were manually removed from the soil samples and washed. Live and dead root fragments were subsequently separated by visual inspection. The xylem of dead roots looks darker and deteriorated, the degree of cohesion between the cortex and the periderm decreases, and root tips become brittle and less resilient (Janssens et al., 2002). Dry biomass was determined after oven-drying at $75^{\circ} \mathrm{C}$ for 2-3 days.

Fine root $(<2 \mathrm{~mm})$ production during the growing season was estimated with a modified in-growth core technique (Lund et al., 1970). The 10 holes created by the root biomass in each plot were refilled early May 2006 with native soil obtained from the root biomass experiment and their boundaries were marked with sticks. The in-growth cores were harvested at the end of October 2006. Soil samples from different depths $(0-5,5-15,15-30,30-45,45-55 \mathrm{~cm})$ for each in-growth core were labeled, and fine root biomass was subsequently estimated using exactly the same procedures as described above. Total fine root production was estimated as the sum of live and dead roots present in the in-growth core in end October 2006.

Fine root turnover rate is defined here as the rate of the total amount of fine root produced in the growing season over the mean standing biomass of fine roots (Aber et al., 1985). Mean fine root biomass was estimated as the average of live root biomass on May, July and September 2006.

\subsection{Decomposition of leaf litter, fine roots, LF-OC, HF-OC and SOC}

Decomposition rates of leaf litter and fine root, LF-OC, HF-OC and SOC were determined using the nylon bag (or litterbag) method (Wen, 1984; Lin et al., 1992, 2005; Arunachalam et al., 1996). Recently fallen leaves, fine root and soil from the $0-10 \mathrm{~cm}$ mineral soil layer were collected from the forests. The fresh soil samples were first passed through a 2-mm sieve. Each nylon bag had a dimension of $10 \mathrm{~cm} \times 15 \mathrm{~cm}$ and a mesh of $1 \mathrm{~mm}$ for leaf litter and fine roots, and of $48 \mu \mathrm{m}$ for soil. 40 nylon bags for Asia white birch and East-Liaoning oak forests and 35 nylon bags for Sharptooth oak forest containing $3 \mathrm{~g}$ of air-dried leaves and fine roots, and $100 \mathrm{~g}$ of air-dried soil were placed in nylon bags and the edges heat-sealed, respectively. In the Asia white birch and East-Liaoning oak forests these nylon bags were inserted on 2 May and collected after $0,30,59,91,123$, 151,179 and 365 days. In the Sharptooth oak forest nylon bags were inserted 10 May and collected after 0, 29, 66, 90, 
Table 1. Initial chemical content of leaf litter, fine root litter, light fraction organic carbon (LF-OC), heavy fraction organic carbon (HF-OC) and total soil organic carbon (SOC) in the $0-10 \mathrm{~cm}$ mineral soil layer used in the decomposition experiments in Asia white birch and EastLiaoning oak forests of warm temperate zone and Sharptooth oak forest of sub-topical zone. Values represent mean \pm standard error $(n=5)$. Different letters in each row are significantly different $(P<0.05)$ according to the least significant difference test.

\begin{tabular}{|c|c|c|c|c|}
\hline & & Asia white $b$ & ch East-Liaoning oak & Sharptooth oak \\
\hline \multirow{3}{*}{ Leaf litter } & $\mathrm{C}\left(\mathrm{g} \mathrm{kg}^{-1}\right)$ & $458 \pm 9$ & $441 \pm 9$ & $450 \pm 8$ \\
\hline & $\mathrm{N}\left(\mathrm{g} \mathrm{kg}^{-1}\right)$ & $12.4 \pm 0.8 \mathrm{a}$ & $9.1 \pm 0.4 b$ & $10.7 \pm 0.6 \mathrm{ab}$ \\
\hline & $\operatorname{Lignin}\left(\mathrm{g} \mathrm{kg}^{-1}\right)$ & $219 \pm 10 b$ & $263 \pm 12 \mathrm{a}$ & $253 \pm 11 a$ \\
\hline \multirow{9}{*}{ Fine root } & Soluble Phenolics $\left(\mathrm{g} \mathrm{kg}^{-1}\right)$ & $36.3 \pm 1.5 b$ & $44.8 \pm 2.2 \mathrm{a}$ & $42.2 \pm 1.8 \mathrm{a}$ \\
\hline & $\mathrm{C}: \mathrm{N}$ & $37.3 \pm 1.6 b$ & $48.9 \pm 2.0 \mathrm{a}$ & $42.4 \pm 1.7 \mathrm{~b}$ \\
\hline & Lignin:N & $18.0 \pm 1.6 \mathrm{~b}$ & $29.4 \pm 2.4 \mathrm{a}$ & $24.0 \pm 2.1 \mathrm{ab}$ \\
\hline & $\mathrm{C}\left(\mathrm{g} \mathrm{kg}^{-1}\right)$ & $443 \pm 9$ & $434 \pm 9$ & $448 \pm 9$ \\
\hline & $\mathrm{N}\left(\mathrm{g} \mathrm{kg}^{-1}\right)$ & $7.4 \pm 0.4$ & $6.6 \pm 0.3$ & $7.0 \pm 0.3$ \\
\hline & Lignin $\left(\mathrm{g} \mathrm{kg}^{-1}\right)$ & $308 \pm 10$ & $332 \pm 16$ & $321 \pm 15$ \\
\hline & Soluble Phenolics $\left(\mathrm{g} \mathrm{kg}^{-1}\right)$ & $20.3 \pm 0.9$ & $23.4 \pm 1.1$ & $22.6 \pm 1.1$ \\
\hline & $\mathrm{C}: \mathrm{N}$ & $60.7 \pm 2.8$ & $65.9 \pm 2.5$ & $64.1 \pm 2.2$ \\
\hline & Lignin:N & $42.1 \pm 1.7$ & $50.4 \pm 2.7$ & $46.3 \pm 3.5$ \\
\hline \multirow{3}{*}{ LF-OC } & $\mathrm{C}\left(\mathrm{g} \mathrm{kg}^{-1}\right.$ soil $)$ & $14.2 \pm 0.2 \mathrm{a}$ & $10.1 \pm 0.2 b$ & $7.9 \pm 0.1 \mathrm{c}$ \\
\hline & $\mathrm{N}\left(\mathrm{g} \mathrm{kg}^{-1}\right.$ soil $)$ & $0.45 \pm 0.01 \mathrm{a}$ & $0.27 \pm 0.01 b$ & $0.23 \pm 0.01 \mathrm{c}$ \\
\hline & $\mathrm{C}: \mathrm{N}$ & $31.8 \pm 0.8 \mathrm{~b}$ & $37.6 \pm 0.9 \mathrm{a}$ & $35.2 \pm 1.1 \mathrm{a}$ \\
\hline \multirow{3}{*}{ HF-OC } & $\mathrm{C}\left(\mathrm{g} \mathrm{kg}^{-1}\right.$ soil $)$ & $40.9 \pm 0.4 \mathrm{a}$ & $35.2 \pm 0.3 b$ & $30.8 \pm 0.3 \mathrm{c}$ \\
\hline & $\mathrm{N}\left(\mathrm{g} \mathrm{kg}^{-1}\right.$ soil $)$ & $2.52 \pm 0.06 \mathrm{a}$ & $2.06 \pm 0.03 b$ & $1.84 \pm 0.02 \mathrm{c}$ \\
\hline & $\mathrm{C}: \mathrm{N}$ & $16.2 \pm 0.3 b$ & $17.1 \pm 0.2 \mathrm{a}$ & $16.7 \pm 0.3 \mathrm{ab}$ \\
\hline \multirow{3}{*}{ Total SOC } & $\mathrm{C}\left(\mathrm{g} \mathrm{kg}^{-1}\right.$ soil $)$ & $55.1 \pm 0.5 \mathrm{a}$ & $45.3 \pm 0.3 b$ & $38.7 \pm 0.2 \mathrm{c}$ \\
\hline & $\mathrm{N}\left(\mathrm{g} \mathrm{kg}^{-1}\right.$ soil $)$ & $2.97 \pm 0.07 \mathrm{a}$ & $2.33 \pm 0.03 b$ & $2.07 \pm 0.03 \mathrm{c}$ \\
\hline & $C: N$ & $18.6 \pm 0.3$ & $19.4 \pm 0.2$ & $18.8 \pm 0.3$ \\
\hline
\end{tabular}

121, 174, 365 days. Five nylon bags were collected at each sampling date. Mass of leaf litter and fine roots in each nylon bag was determined after oven-drying at $75^{\circ} \mathrm{C}$ for $2-3$ days. LF-OC, HF-OC and total SOC of soil in each litterbag were determined using the density fractionation method described above.

At the onset of the decomposition experiments, we also determined total $\mathrm{C}$ and $\mathrm{N}$, lignin and soluble phenol of leaf and fine root material, and total $\mathrm{N}$ of LF-OC, HF-OC and of total SOC. Total C was determined by the standard method of wet-combustion, and total $\mathrm{N}$ by semi-micro Kjeldahl method (Bao, 1999). Lignin was determined with the thioglycolic acid method (Dean, 1997). Soluble phenol concentrations were analyzed using a combination of methanol extraction and the Folin-Ciocalteau assay (Waterman and Mole, 1994). Initial chemical characteristics for the substrates used in the decomposition studies are shown in Table 1.

\subsection{Statistical analysis}

Data management and statistical analyses were performed using SPSS software (SPSS, Chicago, IL). The decay constant $(K)$ and the average rate of litter loss were determined by fitting the following exponential function: $X_{\mathrm{t}}=X_{0} e^{-\mathrm{kt}}$ (Olson, 1963). One-way ANOVA was used to test for significant differences of initial chemical content of leaf litter, fine root, and LF, HF and total soil, soil bulk density, surface organic, coarse woody debris, LF-OC, HF-OC and total SOC, fine root biomass, production and turnover rate. Repeated Measures Analysis of Variance was used to detect the significant differences of seasonal variation of forest floor mass, SMB-C, SMA and fine root biomass. Multiple comparisons were also performed to permit separation of effect means using a least significant difference test at a significance level of $P<0.05$. 
Table 2. Soil organic carbon inputs and pools in Asia white birch and East-Liaoning oak forests of warm temperate zone and Sharptooth oak forest of sub-topical zone. Values represent mean \pm standard error (inputs in $\mathrm{g} \mathrm{C} \mathrm{m}^{-2} \mathrm{yr}^{-1}$; pools in $\mathrm{kg} \mathrm{C} \mathrm{m}^{-2} ; n=5$ ). Different letters in each row are significantly different at $P<0.05$. Labile carbon was assumed to include non-woody surface litter and light-fraction SOC. Recalcitrant carbon was estimated as woody debris plus heavy-fraction SOC.

\begin{tabular}{lccc}
\hline & Asia white birch & East-Liaoning oak & Sharptooth oak \\
\hline Carbon inputs & $30 \pm 3 \mathrm{a}$ & $23 \pm 2 \mathrm{~b}$ & $28 \pm 2 \mathrm{a}$ \\
Woody debris & $142 \pm 8 \mathrm{a}$ & $100 \pm 6 \mathrm{~b}$ & $134 \pm 7 \mathrm{a}$ \\
Above ground litter fall & $165 \pm 15 \mathrm{a}$ & $133 \pm 12 \mathrm{~b}$ & $173 \pm 17 \mathrm{a}$ \\
Fine root turnover & $337 \pm 23 \mathrm{a}$ & $256 \pm 18 \mathrm{~b}$ & $335 \pm 24 \mathrm{a}$ \\
Total & & & \\
& & & \\
SOC pools & $0.6 \pm 0.1 \mathrm{a}$ & $0.6 \pm 0.1 \mathrm{a}$ & $0.5 \pm 0.1 \mathrm{~b}$ \\
Surface layer & $16.1 \pm 0.4 \mathrm{a}$ & $14.5 \pm 0.3 \mathrm{~b}$ & $13.2 \pm 0.2 \mathrm{c}$ \\
SOC & $16.7 \pm 0.4 \mathrm{a}$ & $15.1 \pm 0.3 \mathrm{~b}$ & $13.7 \pm 0.2 \mathrm{c}$ \\
Total & & & \\
& 0.19 & 0.16 & 0.15 \\
Proportion labile & 0.81 & 0.84 & 0.85 \\
Proportion recalcitrant & & & \\
\hline
\end{tabular}

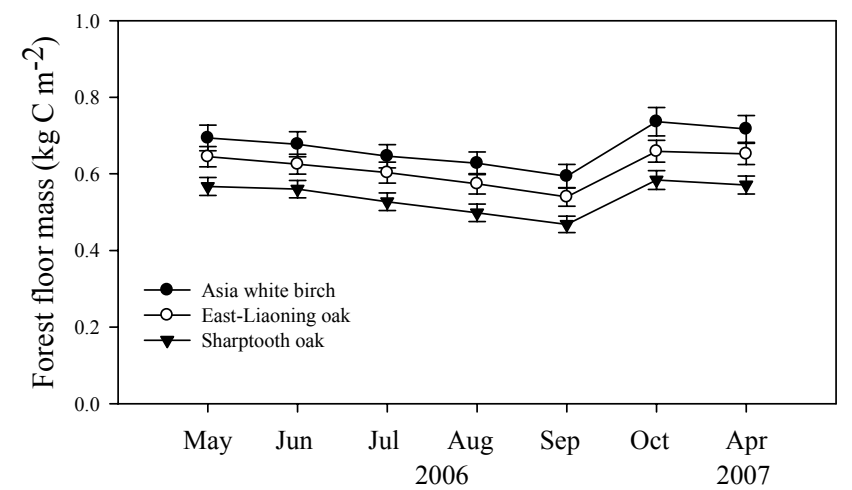

Fig. 1. Seasonal changes of forest floor mass in Asia white birch and East-Liaoning oak forests of warm temperate zone and Sharptooth oak forest of sub-topical zone from May 2006 to April 2007. Vertical bars indicate standard errors of means $(n=5)$.

\section{Results}

\subsection{Soil carbon pools}

The seasonal evolutions of the forest floors in the three investigated forests were relatively similar (Fig. 1), exhibiting a continuous slow decrease until October, when annual leaf litterfall commenced. Nonetheless, total forest floor mass was significantly $(P<0.05)$ higher in the temperate Asia white birch and East-Liaoning oak than in sub-tropical Sharptooth oak forest (Table 2); a difference that was mainly related to differences in the non-woody fraction of the surface organic horizon (Fig. 2). There was no significant difference in coarse woody debris among the three forests (Fig. 2). In the Asia white birch and East-Liaoning oak forest, coarse woody

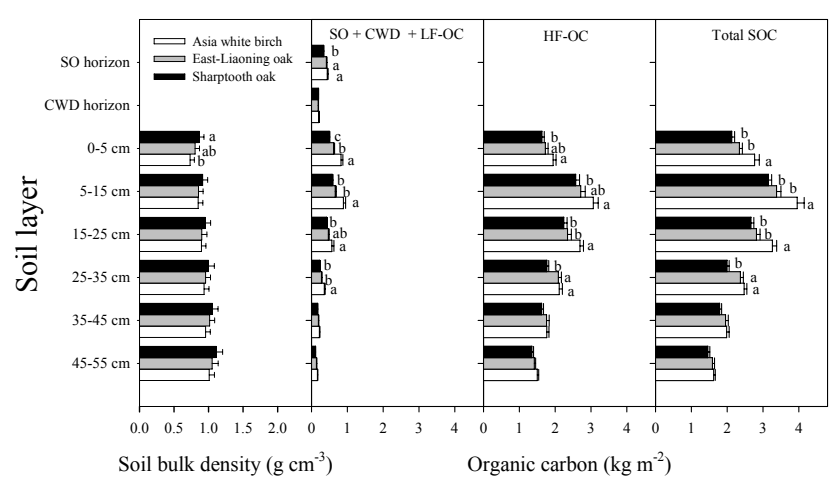

Fig. 2. Vertical distribution of soil bulk density, light fraction organic carbon (LF-OC), heavy fraction organic carbon (HF-OC) and total soil organic carbon (SOC), and carbon of coarse woody debris (CWD) and surface organic (SO) horizon in Asia white birch and East-Liaoning oak forests of warm temperate zone and Sharptooth oak forest of sub-topical zone. Horizontal bars indicate standard errors of means $(n=5)$. Different letters within a soil layer are significantly different $(P<0.05)$ according to the least significant difference test. Absence of letters implies that no significant differences were detected.

debris comprised about $30 \%$ of the forest floor mass, whereas in the less disturbed Sharptooth oak forest coarse woody debris accounted for $36 \%$ of the forest floor mass. In contrast to the non-woody fraction of the forest floor, seasonal fluctuation of woody debris was very little (data not shown).

In the various soil layers down to $55 \mathrm{~cm}$, LF-OC, HFOC and total SOC differed significantly among the studied forests $(P<0.05$, Fig. 2 ; Table 2$)$. In accordance with the carbon stores in the surface horizon, we observed the largest SOC pool in Asia white birch and the lowest in Sharptooth 
Table 3. Mean annual decay/mineralization constants (k) of leaf litter and fine root, and light fraction organic carbon (LF-OC), heavy fraction organic carbon (HF-OC) and total soil organic carbon (SOC) in Asia white birch and East-Liaoning oak forests of warm temperate zone and Sharptooth oak forest of sub-topical zone. Values represent mean \pm standard error derived from eight-time sampling with five replicates for Asia white birch and East-Liaoning oak forests, and seven-time sampling with five replicates for Sharptooth oak forest. Mass loss per year was estimated as: $100 \times$ (initial mass - final mass)/initial mass. Different letters in each column are significantly different $(P<0.05)$ according to the least significant difference test. $R^{2}$, multiple coefficient of determination and significance level of the exponential model $\left({ }^{*} P<0.05 ;{ }^{* *} P<0.01\right)$ are also given.

\begin{tabular}{llccc}
\hline & & $\mathrm{k}$ & $R^{2}$ & Loss $\%$ year $^{-1}$ \\
\hline Leaf litter & Asis white birch & $0.399 \pm 0.100$ & $0.728^{* *}$ & $33.05 \pm 1.28 \mathrm{~b}$ \\
& East-Liaoning oak & $0.267 \pm 0.069$ & $0.715^{* *}$ & $23.14 \pm 1.12 \mathrm{c}$ \\
& Sharptooth oak & $0.483 \pm 0.125$ & $0.751^{*}$ & $39.26 \pm 1.37 \mathrm{a}$ \\
& & & & \\
Fine root & Asis white birch & $0.623 \pm 0.132$ & $0.787^{* *}$ & $45.93 \pm 1.29 \mathrm{~b}$ \\
& East-Liaoning oak & $0.556 \pm 0.110$ & $0.810^{* *}$ & $42.14 \pm 1.01 \mathrm{~b}$ \\
& Sharptooth oak & $0.845 \pm 0.214$ & $0.757^{*}$ & $58.49 \pm 1.48 \mathrm{a}$ \\
& & & & \\
LF-OC & Asis white birch & $0.162 \pm 0.042$ & $0.715^{* *}$ & $14.81 \pm 0.80 \mathrm{~b}$ \\
& East-Liaoning oak & $0.151 \pm 0.038$ & $0.725^{* *}$ & $13.80 \pm 0.64 \mathrm{~b}$ \\
& Sharptooth oak & $0.224 \pm 0.061$ & $0.732^{*}$ & $20.71 \pm 0.98 \mathrm{a}$ \\
& & & & \\
HF-OC & Asis white birch & $0.0475 \pm 0.012$ & $0.710^{* *}$ & $4.67 \pm 0.67$ \\
& East-Liaoning oak & $0.0431 \pm 0.011$ & $0.729^{* *}$ & $4.13 \pm 0.62$ \\
& Sharptooth oak & $0.0547 \pm 0.016$ & $0.710^{*}$ & $5.49 \pm 0.77$ \\
& & & & \\
Total SOC & Asis white birch & $0.0758 \pm 0.02$ & $0.711^{* *}$ & $7.29 \pm 0.69 \mathrm{ab}$ \\
& East-Liaoning oak & $0.0662 \pm 0.017$ & $0.726^{* *}$ & $6.29 \pm 0.62 \mathrm{~b}$ \\
& Sharptooth oak & $0.0868 \pm 0.024$ & $0.716^{*}$ & $8.60 \pm 0.79 \mathrm{a}$ \\
\hline
\end{tabular}

oak forests. Although LF-OC and HF-OC differed among these forests in parallel to total SOC, the relative differences in LF-OC were more pronounced than those in HFOC (the proportion of labile components was lower where total SOC was lowest; Table 2). In absolute terms, labile C amounted to $3.2 \mathrm{~g} \mathrm{C} \mathrm{m}^{-2}$ in Asia white birch, $2.4 \mathrm{~g} \mathrm{C} \mathrm{m}^{-2}$ in East-Liaoning oak and $2.1 \mathrm{~g} \mathrm{C} \mathrm{m}^{-2}$ in Sharptooth oak. In relative terms, the difference in the labile $\mathrm{C}$ pools thus amounts to $50 \%$.

The chemical composition of the various SOC pools also differed among forest types (Table 1 ). If $\mathrm{C}: \mathrm{N}$ ratio, lignin: $\mathrm{N}$ ratio, or soluble phenolics concentrations are used as proxies determining the chemical recalcitrance to microbial decay (Swift et al., 1979; Melillo et al., 1982), then the EastLioning oak forest produced the most recalcitrant organic matter and the Asia white birch the least recalcitrant.

\subsection{Microbial biomass and activity}

In accordance with the SOC availability, mean SMB-C of the two temperate forests was significantly higher than that of the sub-tropical Sharptooth oak forest $(P<0.05$, Fig. 3a). In contrast, SMA exhibited exactly the opposite trend, and this throughout the entire growing season $(P<0.05$, Fig. 3b). In all three forests, both SMB-C and SMA were significantly higher in July than in May and September $2006(P<0.05$, Fig. 3a and b).

The mass loss patterns of decomposing leaf litter, fine roots, LF-OC, HF-OC and total SOC are shown in Fig. 4. Fine roots decomposed fastest (42-58\% mass loss per year; Table 3), followed by leaf litter, LF-OC, Total OC, and last HF-OC that decomposed with an annual mass loss of 4.1$5.5 \%$. Across all litter and SOC types, the decay constant and mass loss rates decreased from Sharptooth oak, Asia white birch to East-Liaoning oak. Differences in decomposition rates were, however, significant only for leaf litter mass, fine root mass, LF-OC and total SOC, and not for HF-OC (Table 3, Fig. 4).

\subsection{Fine root biomass and production}

As with microbial biomass, integrated fine root biomass in the soil layers down to $55 \mathrm{~cm}$ was significantly higher in July than in May and September $(P<0.05$, Fig. 5) in all three forests. Statistically significant differences in fine root biomass among the forests occurred in the $0-35 \mathrm{~cm}$ soil layers in May, and in the 5-25 cm soil layers in July and September $(P<0.05$, Fig. 5$)$.

Integrated over all depths and averaged over the growing season, mean fine root biomass was $0.33 \pm 0.02,0.30 \pm 0.02$ 

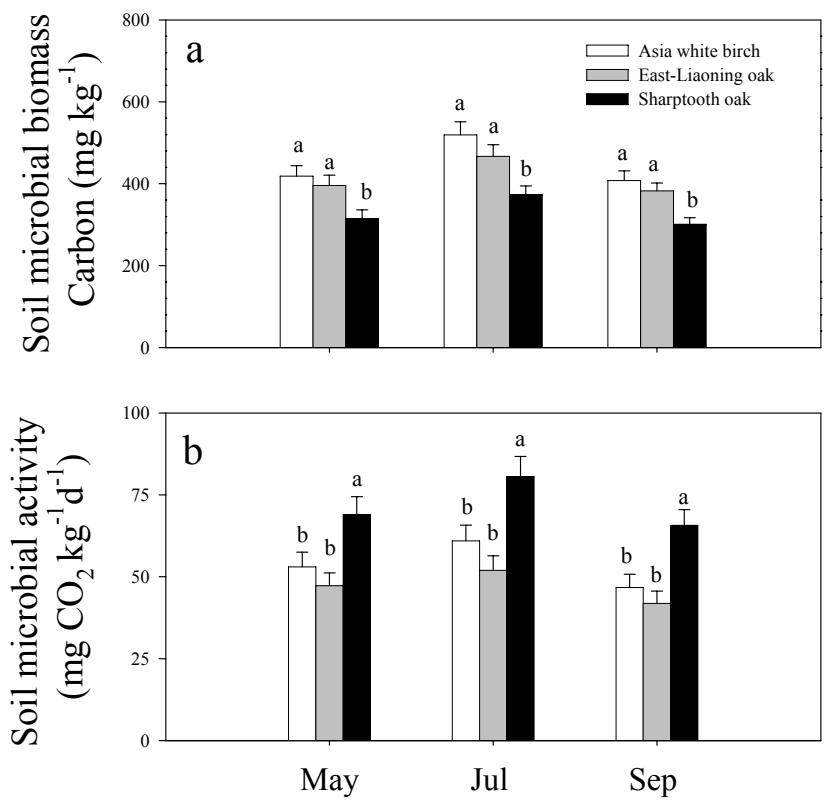

Fig. 3. Soil microbial biomass carbon and soil microbial activity in the $0-15 \mathrm{~cm}$ mineral soil layer in Asia white birch and EastLiaoning oak forests of warm temperate zone and Sharptooth oak forest of sub-topical zone in May, July and September 2006. Vertical bars indicate standard errors of means $(n=5)$. Different letters within a month are significantly different $(P<0.05)$ according to the least significant difference test.

and $0.26 \pm 0.01 \mathrm{~kg} \mathrm{C} \mathrm{m}^{-2}$ in Asia white birch, East-Liaoning oak and Sharptooth oak forests, respectively. However, it should be kept in mind that in the first two forests, almost the entire soil profile was sampled, whereas in the Sharptooth oak forest, where soil depth was around one meter, total fine root biomass was underestimated by sampling only to a depth of $55 \mathrm{~cm}$.

Fine root production in the $0-55 \mathrm{~cm}$ soil layer decreased from Sharptooth oak, Asia white birch to East-Liaoning oak forests, and significant differences were observed in the 0 $25 \mathrm{~cm}$ soil layers (Fig. 6). Integrated over all depths, fine root production was lowest in East-Liaoning oak forests (Table 2).

Fine root turnover rate was thus significantly higher in the sub-tropical Sharptooth oak forest $\left(0.67 \pm 0.06\right.$ year $\left.^{-1}\right)$ than in the temperate Asia white birch $\left(0.50 \pm 0.04\right.$ year $\left.^{-1}\right)$ and East-Liaoning oak forests $\left(0.44 \pm 0.04\right.$ year $\left.^{-1}\right)$.

\subsection{Soil carbon inputs and their residence times}

The seasonal patterns of litterfall were very similar among the different forests, with the majority of the annual litter production in September and October. Seasonal fluctuations in branch litterfall were, however, very little. Annual aboveground litter inputs were significantly $(P<0.05)$ higher in Asia white birch and Sharptooth oak forests than in the EastLiaoning oak forest (Table 2). In agreement with above-

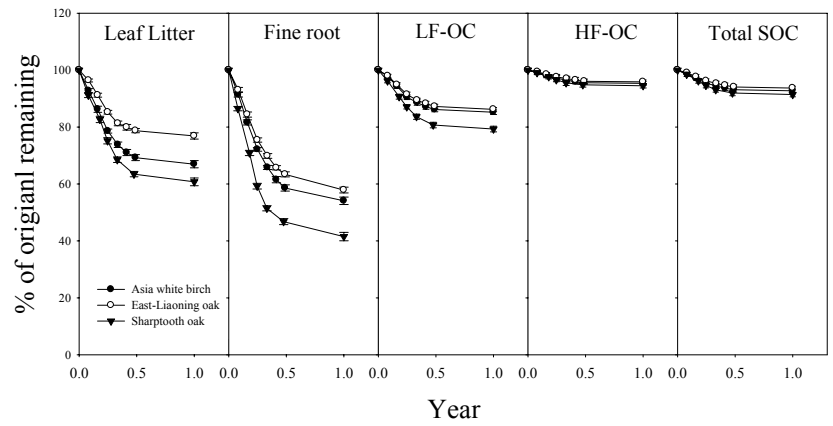

Fig. 4. Leaf litter mass, fine root mass, light-fraction organic carbon (LF-OC), heavy-fraction organic carbon (HF-OC) and total soil organic carbon (SOC) remaining (\% of initial) in Asia white birch and East-Liaoning oak forests of warm temperate zone and Sharptooth oak forest of sub-topical zone during the 1-year period. Vertical bars indicate standard errors of means $(n=5)$.

ground litterfall, below-ground litter production, estimated as being equal to fine root production (under the assumption of interannual steady state in fine root biomass), was also higher in Asia white birch and Sharptooth oak than in EastLiaoning oak (Table 2).

The quality of leaf litter for decomposition decreased in the same order as the quantity of litter inputs. For every measured proxy for the quality of leaf litter for decomposition (soluble phenolics, $\mathrm{C}: \mathrm{N}$ ratio, lignin: $\mathrm{N}$ ratio, lignin content), East-Liaoning oak exhibited the lowest quality litter and Asia white birch the highest (Tables 1 and 3). In contrast to leaf litter, however, fine root quality differed only very slightly among the three tree species.

The residence time of the surface litter inputs in the forest floor (calculated as the ratio of the maximum carbon content in October over the carbon loss between October and September), is much shorter in the sub-tropical Sharptooth oak forest (3.6 years) than in the Asia white birch forest (4.3 years). The East-Liaoning oak forest (5.4 years) has the longest residence time in the forest floor. This pattern is also obtained when the forest floor residence time is calculated from the ratio of forest floor mass over leaf litter inputs. According to this computation, the Sharptooth oak forest floor exhibited a mean residence time of less than three years, whereas carbon resides for more than four years in the forest floor of the East-Liaoning oak forest.

When considering the total unprotected SOC (surface litter+LF-SOC), the residence times calculated as the ratio of the carbon stock over the total litter inputs (above+root litter inputs) follow the same pattern as those in the surface layer. According to these calculations, labile carbon resides in the litter and LF-OC for slightly more than 4 years in the Sharptooth oak forest, up to 6.5 years in the East-Liaoning oak forest, with Asia white birch as an intermediate (5.8 years). 


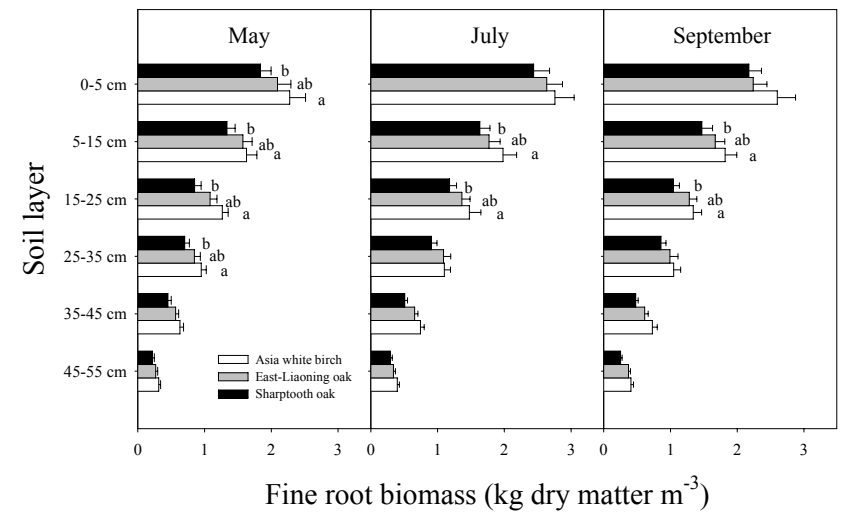

Fig. 5. Vertical distribution of fine root biomass in Asia white birch and East-Liaoning oak forests of warm temperate zone and Sharptooth oak forest of sub-topical zone in May, July and September 2006. Horizontal bars indicate standard errors of means $(n=5)$. Different letters within a soil layer are significantly different $(P<0.05)$ according to the least significant difference test. Absence of letters implies that no significant differences were detected.

\section{Discussion}

\subsection{Decomposition of various SOC types}

Decomposition of litter and SOC is an important process contributing to carbon and nutrient cycling (Vogt et al., 1991; Christensen, 2001; Cornelissen et al., 2007) and is mediated primarily by climate and organic matter quality (Harmon et al., 1990; Sinsabaugh et al., 2002; Fioretto et al., 2007). We assessed decomposition rates by means of litter bags. Litter bag results are prone to errors (both overestimations and underestimations are possible; Swift et al., 1979). One of these errors is the loss or dissolved or particulate through the mazes in the mesh bags. This may be especially relevant in our study, because the Sharptooth oak forest was exposed to much higher precipitation than the other two forests. The reader should bear this potential pitfall in mind, because if important, this would have influenced the calculated turnover rates reported in the results section.

In all three forests, the quality of the SOC for microbial decay decreased in the sequence fine roots, leaf litter, LFOC and HF-OC, as indicated both by decay constants as by the chemical analyses. Moreover, independent of the type of SOC (from fresh litter to HF-SOC), Sharptooth oak always exhibited the fastest decay rates and East-Liaoning oak the slowest. Thus, it appears that the decomposability of the deposited litter is a proxy for the decomposability of the SOC derived from it. It can also not be excluded that the priming mechanism (i.e. a stimulation of decomposition of more recalcitrant material by the addition of labile substrates; Kuzyakov et al., 2000) was more pronounced where the deposited litter was most labile (Subke et al., 2004). Although priming could explain why the order of decay con-

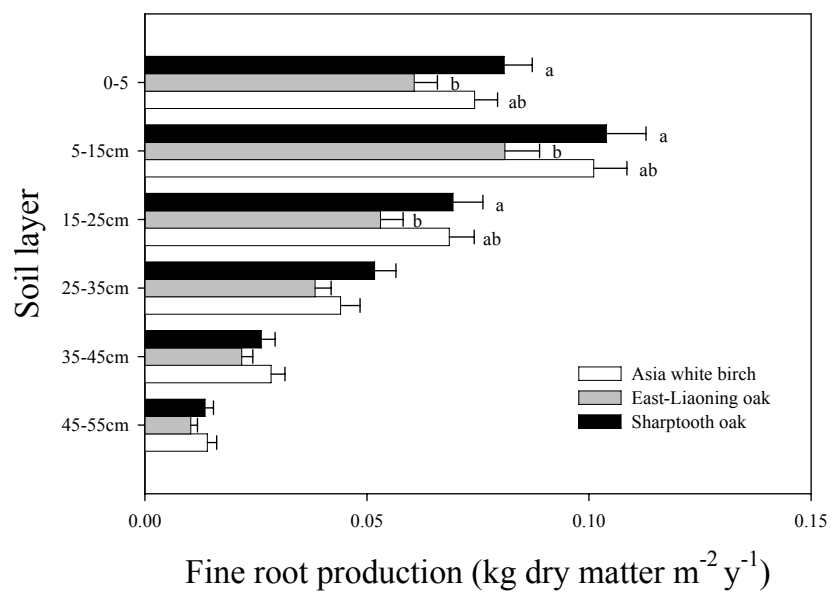

Fig. 6. Vertical distribution of fine root production in Asia white birch and East-Liaoning oak forests of warm temperate zone and Sharptooth oak forest of sub-topical zone. Horizontal bars indicate standard errors of means $(n=5)$. Different letters within a soil layer are significantly different $(P<0.05)$ according to the least significant difference test. Absence of letters implies that no significant differences were detected.

stants across sites is sustained with depth or with substrates of varying recalcitrance, it can not explain why also the chemical proxies varied accordingly. Hence, priming may contribute, but cannot be the sole process explaining why SOC decomposition is highest where litter decomposition is highest.

In agricultural systems, turnover time of LF-OC typically varies from a few months to a few years, while in natural ecosystems turnover times of LF-OC may amount to decades and centuries, depending on local conditions (Post and Kwon, 2000; Leifeld et al., 2009; Schulze et al., 2009). In contrast, HF-OC is stabilized through mineral surface interactions and micro-aggregation (Torn et al., 1997; KögelKnabner et al., 2008) and its turnover time is on the order of decades to millennia (Leifeld et al., 2009; Schulze et al., 2009). In agreement with observations in other studies (Sollins et al., 1996; Swanston et al., 2002), the decay constants of LF-OC were considerably higher than those of HF-OC in all three studied forests. This difference in decay constants is likely mainly attributable to the stabilization by the mineral surfaces, but was nonetheless also related to the differences in $\mathrm{C}: \mathrm{N}$ ratio and lignin: $\mathrm{N}$ ratio, two proxies for decomposability (Melillo et al., 1982). The observed C:N ratio's of the LF-OC were 31-38, and thus within but in the lower end of the range (24-86) observed in forest soils (Strickland and Sollins, 1987; Swanston and Myrold, 1997). The C:N ratio's of HF-OC (16-17) were much lower than those of LF-OC, consistent with other studies (Whalen et al., 2000; Tan et al., 2007). Although the $\mathrm{C} / \mathrm{N}$ ratio was correlated with decomposition rate constants within all of our organic matter types, it cannot explain the differences among 
substrates (the more recalcitrant substrates have lower $\mathrm{C} / \mathrm{N}$ ). It is clear that the lower decomposition rates of HF-OC relative to LF-OC are due to the stronger stabilization mechanisms, and that the higher $\mathrm{N}$ contents are related mainly to the longer residence times and associated degrees of humification.

\subsection{What determines the differences in SOC stocks?}

The observed total soil organic carbon stocks (14$17 \mathrm{~kg} \mathrm{~m}^{-2}$ ) were within, but at the low end of the range reported for forest ecosystems $\left(8-48 \mathrm{~kg} \mathrm{~m}^{-2}\right.$; Dixon et al., 1994). The relatively small pools compared to other forests is, however, probably due to the shallower soils in our study compared to the review by Dixon et al. (1994) and to the low clay contents and thus low potential for SOC stabilization (Torn et al., 1997; Kögel-Knabner et al., 2008). Total soil carbon stocks were lowest in Sharptooth oak forest, highest in Asia white birch, and intermediate in East-Liaoning oak forests. However, it should be kept in mind that in the two temperate forests, the entire soil profile was sampled (bedrock at about $55 \mathrm{~cm}$ ), whereas in the sub-tropical Sharptooth oak forest, where soil depth was around one meter, total SOC was underestimated by sampling to the same depth as in the other forests.

In soils with similar clay contents (as the three study sites included in this study) and assuming similar dominant clay minerals at the sites, one could argue that the stabilization potential of SOC is similar. Under these conditions, SOC contents are determined by the balance of soil carbon inputs and carbon losses. Would it then be possible to explain the observed differences in the SOC stocks with those in the litter inputs and decomposition rates? One prerequisite is for sure that carbon losses other than decomposition do not export substantial amounts of $\mathrm{C}$. Given the steep slopes at the sites, it is likely that part of the deposited litter is transported to the valley bottoms during heavy rains, although we did not observe substantial transport of litter, we can not exclude that this potential loss of surface litter may have confounded our turnover estimates. Nonetheless, all three sites exhibited similar slopes and thus likely similar degrees of erosion and litter transfers, implying that the site comparison is still relevant.

The sub-tropical Sharptooth oak and temperate Asia white birch forest exhibited very similar amounts of litter input, both above- and below-ground. Given the higher quality for decomposition in the Asia white birch forest, as indicated by the chemical composition and decay constants of the litter and LF-OC, one would expect lower SOC stocks in the Asia white birch forest. However, the opposite is observed. Both in the forest floor as in the LF-OC, the residence time in the Asia white birch forest is 50\% higher than in the Sharptooth oak forest and hence, the SOC stocks are $22 \%$ higher in the Asia white birch forest (despite the similar litter inputs). Under the assumption that differences in SOC stabi- lization mechanisms are negligible, this result indicates that the negative effects of the poorer SOC quality on its decay in the Sharptooth oak forest are overshadowed by the positive effects of the more favorable to decomposition sub-tropical climatic conditions.

Does this imply that the differences in chemical composition are unimportant in these deciduous forests? When comparing the two temperate forests, it becomes clear that chemical quality does play a critical role. Although microclimate may have differed, climatic differences are probably minor and thus do not confound the observations. Total litter inputs are 33\% higher in the Asia white birch - than in the East-Liaoning oak forest, yet the total SOC content is only $11 \%$ higher. This discrepancy between site differences in litter inputs and carbon stocks is attributable solely to processes occurring in the surface organic layer. Belowground, the $25 \%$ difference in root litter inputs is reflected in the LF-OC pool, which exhibits a very similar relative difference between both forest types (+29\%). In contrast, aboveground litter fall is $40 \%$ higher in the Asia white birch than in the East-Liaoning oak forest, whereas the forest floor does not significantly differ in carbon content between both forest types (statistically insignificant difference of 7\%). Because leaf litter is of much higher quality in the Asia white birch forest and leaf litter decomposition proceeds much faster, the higher above-ground carbon inputs are almost completely offset by the higher carbon losses due to the difference in above-ground litter quality.

Thus, litter quality is a very important determinant of SOC cycling in these temperate forests, but among our study sites less so than the effect of climate. Nonetheless, we would like to re-iterate that this reasoning only holds if erosion and litter export by heavy rains are comparable in the two temperate sites (which are likely given the same climate, slopes, and soil types).

\subsection{Soil microbial biomass and activity}

Soil microbial biomass represents an important labile pool of nutrients and carbon (Henrot and Robertson, 1994). Changes in the size of the microbial biomass pool may indicate changes in the substrate availability that are otherwise not easily detectable. In this study, SMB-C and SMA were higher in July than in May and September in all three forests, reflecting that substrate availability must have varied considerably during the growing season. Similar findings were also observed in other studies (Wardle, 1998; Michelsen et al., 2004; Shishido et al., 2008).

Soil microbial biomass of the sub-tropical Sharptooth oak forest was lower than that of East-Liaoning oak and Asia white birch forests. This pattern reflected well that of the labile SOC pools, confirming that substrate availability might be an important control over the size of the SMB-C pool (Wardle, 1992). 
In contrast to SMB-C, SMA was higher in the Sharptooth oak forest than in the Asia white birch and East-Liaoning oak forests. This pattern was very surprising given that SMA was determined in the lab under similar climatic conditions, and that the Sharptooth oak soil contained the least available SOC, which also was less degradable than the SOC in the Asia white birch soil. Based on the observed SOC quantity and quality, we would have expected the highest SMA in the Asia white birch, and lower ones in the Sharptooth oak forest because of the lower SOC availability. We can only speculate why the SMA observations contrasted our expectations. One potential explanation could be that the environmental conditions in the lab during the SMA experiments resembled the climatic conditions in the sub-tropical Sharptooth oak forest much better (both in terms of temperature and soil moisture) than in the two temperate-zone forests. Soil microbial population may adapt either physiologically or structurally to temperature (e.g. Bradford et al., 2008) and perhaps the warm and moist conditions during the lab incubations were more optimal for the microbial populations in the subtropical soil, and supra-optimal for those in the temperate soils.

\subsection{Fine root dynamics}

Our estimates of mean fine root biomass (between 510 and $660 \mathrm{~g}$ dry matter $\mathrm{m}^{-2}$ ) were well within the range reported by Vogt et al. (1996) for fine root biomass in temperate broadleaved forests $\left(243-999 \mathrm{~g}\right.$ dry matter $\left.\mathrm{m}^{-2}\right)$. Fine root growth at our study sites $(270$ to $350 \mathrm{~g}$ dry matter $\mathrm{m}^{-2}$ year ${ }^{-1}$ ) was much higher relative to that of a temperate oak forest in a more moderate, maritime climate (Quercus robur; fine root productivity of $180 \mathrm{~g}$ dry matter $\mathrm{m}^{-2}$ year $^{-1}$; Curiel Yuste et al., 2005). Luyssaert et al. (2007) reported a fine root productivity average across 52 temperate deciduous forests of $440 \mathrm{~g}$ dry matter $\mathrm{m}^{-2}$ year $^{-1}$ (recalculated from carbon units assuming that dry matter contains $50 \%$ carbon). Although our sites are all below this global average, they are all well within the $25-75 \%$ percentile range (204-460 g dry matter $\mathrm{m}^{-2}$ year $^{-1}$ ) reported in the review by Luyssaert and co-workers (2007).

Fine root biomass and - production both decreased with soil depth. Similar findings have been observed in many studies (Vogt et al., 1981; Olsthoorn, 1991; Xiao et al., 2003; Konôpka et al., 2006) and have been attributed to declining nutrient availability and changing physical conditions with depth. Also fine root turnover declined with depth (data not shown). Averaged over all depths, turnover of roots $<2 \mathrm{~mm}$ at our sites $\left(0.45\right.$ to 0.67 year $\left.^{-1}\right)$ was lower than the global mean turnover rate $\left(0.8\right.$ year $\left.^{-1}\right)$ for forest fine roots $<2 \mathrm{~mm}$ reported in the review by Gill and Jackson (2000), but nonetheless well within the range for broadleaf forests in similar climates $\left(0.2-1.4\right.$ year $\left.^{-1}\right)$.

It should be noted that estimates of fine root productivity are notoriously difficult and that different techniques can produce largely different estimates, even within the same site
(Gill and Jackson, 2000; see Milchunas, 2009 for an intercomparison study of most applied techniques). As stated by Milchunas (2009), the ingrowth core technique applied here may produce either over- or underestimations, depending on specific methodological details. It is therefore extremely difficult to quantify the accuracy of our root production - (and thus also root turnover) estimates. Nonetheless, because we applied the same methodology at all three sites, it is fair to assume that the relative differences can provide valuable information. The faster root turnover in the Asia white birch forest relative to the East-Liaoning oak forest, for instance, thus provides important information. Rates of root turnover are influenced by climate (Vogt et al., 1986; Hendrick and Pregitzer, 1993; Pregitzer et al., 2000) and nutrient availability (Crick and Grime, 1987; Schoettle and Fahey, 1994; Janssens et al., 2002), amongst others. Root functioning is optimal when the resource capture efficiency (uptake of nutrients or water per unit $\mathrm{C}$ cost) is maximized (Eissenstat and Van Rees, 1994). Rapid fine root turnover constitutes a large energy and nutrient cost for the plant, while long lifespans result in reduced rates and lower efficiency of resource uptake (Schoettle and Fahey, 1994). Rapid root turnover may be advantageous in nutrient-rich environments, where resource capture efficiency is likely to be maximized by reducing root longevity, thus simultaneously increasing nutrient uptake capacity and reducing root maintenance costs (Crick and Grime, 1987). In contrast, increased longevity would be more favourable under highly competitive, nutrient-poor conditions because nutrient losses through root mortality will need to be avoided.

The difference in root turnover in our two temperate forests can not be climate driven and might thus be related to faster decomposition rates and thus nutrient cycling. The higher fine root turnover rate observed in the sub-tropical Sharptooth oak forest might be due merely to the warmer and wetter conditions, that favour root production (Gill and Jackson, 2000). However, as discussed above, the more favourable climate also accelerates decomposition and thus nutrient availability to roots (Wardle, 1992; Zaman et al., 1999; Gill and Jackson, 2000; Tu et al., 2003; Xiao et al., 2007). Hence, it is impossible to state from this limited number of forest sites whether climate or nutrient cycling is the dominant control over root turnover.

In conclusion, our results show that there are obvious differences in pool size and decomposition rates of litter and SOC, SMB-C and SMA, and fine root biomass, production and turnover rate among Asia white birch, East-Liaoning oak and Sharptooth oak forests. These results provide basic information in estimating the effectiveness of belowground carbon dynamics and sequestration in the three forests.

Acknowledgements. The authors are grateful to two anonymous referees and the editor for providing numerous comments that substantially improved this manuscript. This study was financially supported by the National Basic Research Program of China (973 Program No. 2009CB825103 and 2007CB106806), the Chinese 
Academy of Sciences (KZCX2-YW-JC303), the National Natural Science Foundation of China (No. 30570297), and State Key Laboratory of Vegetation and Environmental Change, Institute of Botany, the Chinese Academy of Sciences. We gratefully acknowledge the Beijing Forest Ecosystem Station of the Institute of Botany of the Chinese Academy of Sciences and National Field Station for Forest Ecosystem in Shennongjia, Hubei and Administration Bureau of Shennongjia National Nature Reserve for help with logistics and access permission to these study sites. IAJ acknowledges support from the Flemish National Science Foundation.

Edited by: J. Leifeld

\section{References}

Aber, J. D., Melillo, J. M., Nadelhoffer, K. J., McClaugherty, C. A., and Pastor, J.: Fine root turnover in forest ecosystems in relation to quantity and form of nitrogen availability: a comparison of two methods, Oecologia, 66, 317-321, 1985.

Arunachalam, A., Pandey, H. N., Tripathi, R. S., and Maithani, K.: Fine root decomposition and nutrient mineralization patterns in a subtropical humid forest following tree cutting, Forest Ecol. Manag., 86, 141-150, 1996.

Bao, S. D.: Agriculture Soil Chemical Analysis, Science Press, Beijing, China, 263-271, 1999.

Bradford, M. A., Davies, C. A., Frey, S. D., Maddox, T. R., Melillo, J. M., Mohan, J. E., Reynolds, J. F., Treseder, K. K., and Wallenstein, M. D.: Thermal adaptation of soil microbial respiration to elevated temperature, Ecol. Lett., 11, 1316-1327, 2008.

Callesen, I., Liski, J., Raulund-Rasmussen, K., Olsson, M. T., TauStrand, L., Vesterdal, L., and Westman, C. J.: Soil carbon stores in Nordic well-drained forest soils - relationships with climate and texture class, Glob. Change Biol., 9, 358-370, 2003.

Chen, L. Z.: Study on the Structure and Function of Warm Temperate Forest Ecosystems, Science Press, Beijing, China, 1997.

Christensen, B. T.: Physical fractionation of soil and structural and functional complexity in organic matter turnover, Eur. J. Soil Sci., 52, 345-353, 2001.

Cornelissen, J. H. C., van Bodegom, P. M., Aerts, R., et al.: Global negative vegetation feedback to climate warming responses of leaf litter decomposition rates in cold biomes, Ecol. Lett., 10, 619-627, 2007.

Crick, J. C. and Grime, J. P.: Morphological plasticity and mineral nutrient capture in two herbaceous species of contrasted ecology, New Phytol., 107, 403-414, 1987.

Curiel Yuste, J., Konôpka, B., Janssens, I. A., Coenen, K., Xiao, C. W., and Ceulemans, R.: Contrasting net primary productivity and carbon distribution between neighboring stands of Quercus robur and Pinus sylvestris, Tree Physiol., 25, 701-712, 2005.

Curtis, P. S., Hanson, P. J., Bolstad, P., Barford, C., Randolph, J. C., Schmid, H. P., and Wilson, K. B.: Biometric and eddycovariance based estimates of annual carbon storage in five eastern North American deciduous forests, Agr. Forest Meteorol., 113, 3-19, 2002.

Davidson, E. A. and Janssens, I.: Temperature sensitivity of soil carbon decomposition and feedbacks to climate change, Nature, 440, 165-173, 2006.

Davidson, E. A., Trumbore, S. E., and Amundson, R.: Soil warming and organic carbon content, Nature, 408, 789-790, 2000.
Dean, J. F. D.: Lignin analysis, in: Methods in Plant Biochemistry and Molecular Biology, edited by: Dashek, W. V., CRC Press, Boca Raton, 199-215, 1997.

Delectis Flora Reipublicae Popularis Sinicae Agendae Academiae Sinicae Edita: Flora Reipublicae Popularis Sinicae, Tomus 21: Angiospermae Dicotyledoneae Myricaceae Juglandaceae Betulaceae, Science Press, Beijing, China, 1979.

Delectis Flora Reipublicae Popularis Sinicae Agendae Academiae Sinicae Edita: Flora Reipublicae Popularis Sinicae, Tomus 22: Angiospermae Dicotyledoneae, Science Press, Beijing, China, 1998.

Dixon, R. K., Brown, S., Houghton, R. A., Solomon, A. M., Trexler, M. C., and Wisniewski, J.: Carbon pools and flux of global forest ecosystems, Science, 263, 185-190, 1994.

Elliott, E. T. and Paustian, T. K.: Modelling the measurable or measuring the modelable: a hierarchical approach to isolating meaningful soil organic matter fractionations, in: Evaluation of Soil Organic Matter Models Using Existing Long-Term Datasets, edited by Powlson, D. S., Smith, P., Smith, J. U., NATO ASI Series 1, Global Environ. Chang., Springer-Verlag, Heidelberg, 38, 161-179, 1996.

Eissenstat, D. M. and Van Rees, K. C. J.: The growth and function of pine roots, Ecol. Bull., 43, 76-91, 1994.

Fang, J. Y., Liu, G. H., Zhu, B., Wang, X. K., and Liu, S. H.: Carbon budgets of three temperate forest ecosystems in Dongling Mt., Beijing, China, Sci. China Ser. D., 50, 92-101, 2007.

FAO-WRB (ISSS-ISRIC-FAO-UNESCO): World Reference Base for Soil Resources, FAO, Wold Soil Resources Report No. 84, Rome, Italy, 1998.

Feng, Z. W., Wang, X. K., and Wu, G.: Biomass and Net Production of Forest Vegetation in China, Science Press, Beijing, China, 1999.

Fioretto, A., Papa, S., Pellegrino, A., and Fuggi, A.: Decomposition dynamics of Myrtus communis and Quercus ilex leaf litter: Mass loss, microbial activity and quality change, Appl. Soil Ecol., 36, 32-40, 2007.

Gill, R. A. and Jackson, R. B.: Global patterns of root turnover for terrestrial ecosystems, New Phytol., 147, 13-31, 2000.

Golchin, A., Clarke, P., Oades, J. M., and Skjemstad, J. O.: The effects of cultivation on the composition of organic matter and structural stability of soils, Aust. J. Soil Res., 33, 975-993, 1995.

Golchin, A., Oades, J. M., Skjemstad, J. O., and Clarke, P.: Study of free and occluded particulate organic matter in soils by solidstate ${ }^{13}$ CNMR spectroscopy and scanning electron microscopy, Aust. J. Soil Res., 32, 285-309, 1994.

Harmon, M. E., Baker, G. A., Spycher, G., and Greene, S.: Leaf litter decomposition in Picea/tsuga forests of Olympic National Park, Washington, USA, Forest Ecol. Manag., 31, 55-66, 1990.

Hendrick, R. L. and Pregitzer, K. S.: The dynamics of fine root length, biomass, and nitrogen content in two northern hardwood ecosystems, Can. J. Forest Res., 23, 2507-2520, 1993.

Henrot, J. and Robertson, G. P.: Vegetation removal in two soils of the humid tropics: effect on microbial biomass. Soil Biol. Biochem., 26, 111-116, 1994.

Houghton, J. T., Ding, Y., Griggs, D. J., Noguer, M., van der Linden, P. J., Dai, X., Maskell, K., and Johnson, C. A.: IPCC 2001: Climate Change 2001: the Scientific Basis, Cambridge University Press, New York, USA, 2001.

$\mathrm{Hu}, \mathrm{S}$. and van Bruggen, A. H. C.: Microbial dynamics associated 
with multiphasic decomposition of 14C-labeled cellulose in soil, Microb. Ecol., 33, 134-143, 1997.

Janssens, I. A., Sampson, D. A., Curiel Yuste, J., Carrara, A., and Ceulemans, R.: The carbon cost of fine root turnover in a Scots pine forest, Forest Ecol. Manag., 168, 231-240, 2002.

Kögel-Knabner, I., Guggenberger, G., Kleber, M., Kandeler, E., Kalbitz, K., Scheu, S., Eusterhues, K., and Leinweber, P.: Organo-mineral associations in temperate soils: integrating biology, mineralogy, and organic matter chemistry, J. Plant Nutr. Soil Sc., 171, 61-82, 2008.

Konôpka, B., Noguchi, K., Sakata, T., Takahashi, M., and Konôpková, Z.: Fine root dynamics in a Japanese cedar (Cryptomeria japonica) plantation throughout the growing season, Forest Ecol. Manag., 225, 278-286, 2006.

Kuzyakov, Y., Friedel, J. K., and Stahr, K.: Review of mechanisms and quantification of priming effects, Soil Biol. Biochem., 32, 1485-1498, 2000.

Leifeld, J., Zimmermann, M., Fuhrer, J., and Conen, F.: Storage and turnover of carbon in grassland soils along an elevation gradient in the Swiss Alps, Glob. Change Biol., 15, 668-679, 2009.

Li, Y., Xu, M., Zou, X. M., Shi, P. J., and Zhang, Y. Q.: Comparing soil organic carbon dynamics in plantation and secondary forest in wet tropics in Puerto Rico, Glob. Change Biol., 11, 239-248, 2005.

Lin, X. X., Wu, S. L., and Che, Y. P.: Method of nylon bag for measuring decomposition rate of organic materials in arid and semi-arid and humid region, Soils, 24, 315-318, 1992.

Lovell, R. D., Jarvis, S. C., and Bardgett, R. D.: Soil microbial biomass and activity in long-term grassland: effects of management changes, Soil Biol. Biochem., 27, 969-975, 1995.

Lund, Z. F., Pearson, R. W., and Buchanan, G. A.: An implanted soil mass technique to study herbicide effects on root growth, Weed Sci., 18, 279-281, 1970.

Luyssaert, S., Inglima, I., Jung, M., et al.: $\mathrm{CO}_{2}$ balance of boreal, temperate, and tropical forests derived from a global database, Glob. Change Biol., 13, 2509-2537, 2007.

Melillo, J. M., Aber, J. D., and Muratore, J. F.: Nitrogen and lignin control of hardwood leaf litter decomposition dynamics, Ecology, 63, 621-626, 1982.

Michelsen, A., Andersson, M., Jensen, M., Kjøller, A., and Gashew, M.: Carbon stocks, soil respiration and microbial biomass in fireprone tropical grassland, woodland and forest ecosystems, Soil Biol. Biochem., 36, 1707-1717, 2004.

Milchunas, D. G.: Estimating root production: Comparison of 11 methods in shortgrass steppe and review of biases, Ecosystems, 12, 1381-1402, 2009.

Müller, P. E.: Recherches sur les formes naturelles de l'humus et leur influence sur la végétation et le sol. (translated from danish), Ann. Sci. Agronom., 1, 85-423, 1889.

Olson, J. S.: Energy storage and the balance of producers and decomposers in ecological systems, Ecology, 44, 322-331, 1963.

Olsthoorn, A. F. M.: Fine root density and root biomass of two Douglas-fir stands on sandy soils in The Netherlands: 2. Periodicity of fine root growth and estimation of belowground carbon allocation, Neth. J. Agr. Sci., 39, 49-60, 1991.

Post, W. M., Emanuel, W. R., Zinke, P. J., and Stangenberger, A. G.: Soil carbon pools and world life zones, Nature, 298, 156159, 1982.

Post, W. M. and Kwon, K. C.: Soil carbon sequestration and landuse change: processes and potential, Glob. Change Biol., 6, 317327, 2000.

Pregitzer, K. S., King, J. A., Burton, A. J., and Brown, S. E.: Responses of tree fine roots to temperature, New Phytol., 147, 105$115,2000$.

Roberts, J.: A study of root distribution and growth in a Pinus sylvestris L. (Scots pine) plantation in East Anglia, Plant Soil, 44, 607-621, 1976.

Schoettle, A. W. and Fahey, T. J.: Foliage and fine root longevityof pines, Ecol. Bull., 43, 136-153, 1994.

Schulze, K., Borken, W., Muhr, J., and Matzner, E.: Stock, turnover time and accumulation of organic matter in bulk and density fractions of a Podzol soil, Eur. J. Soil Sci., 60, 567-577, 2009.

Shishido, M., Sakamoto, K., Yokoyama, H., Momma, N., and Miyashita, S.: Changes in microbial communities in an apple orchard and its adjacent bush soil in response to season, land-use, and violet root rot infestation, Soil Biol. Biochem., 40, 14601473, 2008.

Sinsabaugh, R. L., Carreiro, M. M., and Alvarez, S.: Enzyme and microbial dynamics of litter decomposition, in: Enzymes in the Environment: Activity, Ecology and Applications, edited by: Burns, R. C., Dick, R. P., Marcel, Dekker Inc., 249-265, 2002.

Six, J., Elliott, E. T., and Paustian, K.: Soil structure and soil organic matter: II. A normalized stability index and the effect of mineralogy, Soil Sci. Soc. Am. J., 64, 1042-1049, 2000.

Sollins, P., Homann, P., and Caldwell, B. A.: Stabilization and destabilization of soil organic matter: mechanisms and controls, Geoderma, 74, 65-105, 1996.

Sollins, P., Spycher, G., and Glassman, C. A.: Net nitrogen mineralization from light- and heavy-fraction forest soil organic matter, Soil Biol. Biochem., 16, 31-37, 1984.

Stephenson, N. L. and van Mantgem, P. J.: Forest turnover rates follow global and regional patterns of productivity, Ecol. Lett., 8, 524-531, 2005.

Strickland, T. C. and Sollins, P.: Improved method for separating light and heavy fraction organic matter from soil, Soil Sci. Soc. Am. J., 51, 1390-1393, 1987.

Subke, J. A., Hahn, V., Battipaglia, G., Linder, S., Buchmann, N., and Cotrufo, M. F.: Feedback interactions between needle litter decomposition and rhizosphere activity, Oecologia, 139, 551559, 2004.

Swanston, C. W., Caldwell, B. A., Homann, P. S., Ganio, L., and Sollins, P.: Carbon dynamics during a long-term incubation of separate and recombined density fractions from seven forest soils, Soil Biol. Biochem., 34, 1121-1130, 2002.

Swanston, C. W. and Myrold, D. D.: Incorporation of nitrogen from decomposing red alder leaves into plants and soil of a recent clearcut in Oregon, Can. J. Forest Res., 27, 1496-1502, 1997.

Swift, M. J., Heal, O. W., and Anderson, J. M.: Decomposition in Terrestrial Ecosystems, Blackwell Scientific Publications, Oxford, UK, 362 pp., 1979.

Tan, Z., Lal, R., Owens, L., and Izaurralde, R. C.: Distribution of light and heavy fractions of soil organic carbon as related to land use and tillage practice, Soil Till. Res., 92, 53-59, 2007.

Torn, M. S., Trumbore, S. E., Chadwick, O. A., Vitousek, P. M., and Hendricks, D. M.: Mineral control of soil organic matter storage and turnover, Nature, 389, 170-173, 1997.

Tu, C., Koenning, S. R., and Hu, S.: Root-parasitic nematodes enhance soil microbial activities and nitrogen mineralization, Mi- 
crob. Ecol., 46, 134-144, 2003.

Vance E. D., Brookes, P. C., and Jenkinson, D. S.: An extraction method for measuring soil microbial biomass C, Soil Biol. Biochem., 19, 703-707, 1987.

Vogt, K. A., Edmonds, R. L., and Grier, C. C.: Seasonal changes in biomass and vertical distribution of mycorrhizal and fibroustextured conifer fine roots in 23- and 180-year-old subalpine Abies amabilis stands, Can. J. Forest Res., 11, 223-229, 1981.

Vogt, K. A., Grier, C. C., and Vogt, D. J.: Production, turnover, and nutrient dynamics of above- and belowground detritus of world forests, Adv. Ecol. Res., 15, 303-377, 1986.

Vogt, K. A., Vogt, D. J., and Bloomfield, J.: Input of organic matter to the soil by tree roots, in: Plant Roots and their Environment, edited by: McMichael, B. L. and Persson, H., Elsevier Science Publishers, Amsterdam, Netherlands, 171-190, 1991.

Vogt, K. A., Vogt, D. J., Palmiotto, P. A., Boon, P., O'Hara, J., and Asbjornsen, H.: Review of root dynamics in forest ecosystems grouped by climate, climatic forest type and species, Plant Soil, 187, 159-219, 1996.

Wardle, D. A.: A comparative assessment of factors which influence microbial biomass carbon and nitrogen levels in soil, Biol. Rev. Camb. Philos., 67, 321-358, 1992.

Wardle, D. A.: Controls of temporal variability of the soil microbial biomass: a global-scale synthesis, Soil Biol. Biochem., 30, 1627-1637, 1998.
Waterman, P. G. and Mole, S.: Analysis of Phenolic Plant Metabolites, Blackwell Scientific, Oxford, UK, 1994.

Wen, Q. X.: Study Methods of Soil Organic Matter, Agricultural Press, Beijing, China, 1984.

Whalen, J. K., Bottomley, P. J., and Myrold, D. D.: Carbon and nitrogen mineralization from light- and heavy-fraction additions to soil, Soil Biol. Biochem., 32, 1345-1352, 2000.

Xiao, C. W., Curiel-Yuste, J., Janssens, I. A., Roskams, P., Nachtergale, L., Carrara, A., Sanchez, B. Y., and Ceulemans, R.: Aboveand belowground biomass and net primary production in a 73year-old Scots pine forest, Tree Physiol., 23, 505-516, 2003.

Xiao, C. W., Janssens, I. A., Liu, P., Zhou, Z. Y., and Sun, O. J.: Irrigation and enhanced soil carbon input effects on below-ground carbon cycling in semiarid temperate grasslands, New Phytol., 174, 835-846, 2007.

Zaman, M., Di, H. J., and Cameron, K. C.: A field study of gross rates of $\mathrm{N}$ mineralization and nitrification and their relationships to microbial biomass and enzyme activities in soils treated with dairy effluent and ammonium fertilizer, Soil Use Manage., 15, 188-194, 1999.

Zimmermann, M., Leifeld, J., Schmidt, M. W. I., Smith, P., and Fuhrer, J.: Measured soil organic matter fractions can be related to pools in the RothC model, Eur. J. Soil Sci., 58, 658-667, 2007. 